\title{
The future of olive groves on sloping land and ex-ante assessment of cross compliance for erosion control
}

\author{
Jan de Graaffa,*, Filomena Duarte ${ }^{\mathrm{b}}$, Luuk Fleskens ${ }^{\mathrm{c}}$, Tomás de Figueiredo ${ }^{\mathrm{d}}$ \\ a Erosion and Soil \& Water Conservation Group, Wageningen University, The Netherlands \\ ${ }^{\mathrm{b}}$ Instituto Superior de Economia Agraría e Sociologia Rural, Lisboa, Portugal \\ c National Agricultural Research Institute, c/o Toker Integrated Community Development Project, Asmara, Eritrea \\ d Escola Superior de Bragança, Quinta de Santa Apolonia, Bragança, Portugal
}

\section{A R T I C L E I N F O}

\section{Article history:}

Received 30 July 2007

Received in revised form 11 February 2008

Accepted 20 February 2008

\section{Keywords:}

Olive groves

Policies

Soil erosion

Cross compliance

Scenarios

\begin{abstract}
A B S T R A C T
Under the past Common Agricultural Policy (CAP) olive oil subsidy regime, farmers were eligible for subsidies on the basis of the amount of olive oil they produced. This led to an intensification of production, particularly on flat land, and had in most cases negative environmental effects, such as more soil erosion on sloping land and more pollution. With the decoupling of agricultural support under the newly established rules of the CAP, formalised in 2005, cross compliance measures have become obligatory.

In this paper an ex-ante assessment is made of the application of cross compliance for soil erosion control (natural cover crops and terrace maintenance) in hilly and mountainous olive groves in Trás-osMontes in Portugal. A linear programming model was developed to assess the various socio-economic and environmental effects of four different development scenarios for olive groves. The scenarios were developed on the basis of changing market prices, wage rates and subsidies; their effects included shifts towards intensification, abandonment and organic farming. Simulations considering a minimum return to labour constraint showed very high levels of abandonment, particularly in combination with cross compliance obligations. However, even without this minimum return to labour constraint, abandonment would reach more than $20 \%$ in three out of the four scenarios. The model showed that cross compliance obligations could be quite effective in reducing erosion, but that they would depress income in all scenarios as a result of higher abandonment and lower percentage shifts towards intensive systems.
\end{abstract}

(c) 2008 Elsevier Ltd. All rights reserved.

\section{Introduction}

During the 3-year period 2003-2006, the EU project OLIVERO undertook physical and socio-economic research on Sloping and Mountainous Olive Production Systems (SMOPS) in five target areas in southern Europe (Stroosnijder et al., in press). In these target areas 24 different SMOPS were distinguished, with their productive, ecological, economic and social functions (Metzidakis, 2004), and these were grouped into five major types: traditional, semi-intensive low input, semi-intensive high input, intensive and organic production systems (Fleskens, 2005).

While analysing the future prospects of the SMOPS, several key issues were identified that would need to be tackled for the future development of these production systems (de Graaff, 2005). Local olive sector specialists often mentioned soil erosion as a major key

\footnotetext{
* Corresponding author at: Droevendaalsesteeg 4, 6708 PB, Wageningen, The Netherlands. Tel.: +31 317482881; fax: +31 317491000 .

E-mail address: Jan.deGraaff@wur.nl (J. de Graaff).
}

issue, as well as problems such as pests and diseases, low productivity, financial losses and pollution (Fleskens and de Graaff, 2006). In most target areas, and in particular in Spain, there is indeed much concern about soil erosion (Pastor and Castro, 1995; Gómez et al., 2005).

For environmental and social reasons, among others, proposals were made in 1997 for changing the EU support policies for the olive sector (EC, 1997). Production aid has been the main Common Agricultural Policy (CAP) tool to support farmers' income and this had multiple effects on rural areas (Brouwer and Lowe, 2000). This was particularly the case since 1998 when, after a transitional reform of the Common Market Organization (CMO), support to olive farmers became linked to current output for each producer. Under such a support scheme there was a clear incentive to intensify production; thus small producers in marginal areas, with old, less productive trees and no access to irrigation, were at a disadvantage (Beaufoy, 2000; Duarte et al., 2006). With production intensification, negative environmental effects (e.g. soil erosion, decreased biodiversity, high water use and pollution) became a main feature of many olive growing areas in Spain, Greece, Italy and Portugal (Beaufoy, 2001). 
Suggestions were made to revise the subsidy system in such a way as to consider both production and environmental aspects (de Graaff and Eppink, 1999). In 2004, the olive and olive oil regime was formally changed, whereby support to olive farmers was integrated in the Single Payment Scheme (SPS), following a pattern similar to the one introduced in 2003 for the main arable crops (EC, 2005). The SPS regime for olives became effective in 2006.

Under the new rules, entitlements were decoupled from current production and would become fixed amounts per year, equal to at least $60 \%$ of the average production aid payments during the 4 -year reference period (1999 through 2002). The remaining portion (up to $40 \%$ ) was supposed to be retained by Member States as national envelopes, to be distributed, as aid per ha (shown in GIS developed for areas under olives), to a maximum of five categories of olive groves with relevant environmental/social functions. However, all major producing countries (except Spain, to a small extent) have now decided in favour of total decoupling, so that there is now full integration of olive support in the SPS.

According to de Graaff et al. (in press), the partial decoupling could have contributed to several social and environmental purposes, including:

- To avoid environmental harm to abandoned plantations.

- To assure that traditional farmers in remote areas, with few employment opportunities, could stay in (the olive) business.

- To avoid massive abandonment and/or social isolation in such areas.

- To maintain some standards of biodiversity and landscape management.

- To establish cost-effective soil erosion control measures on steep slopes.

- To control pollution and efficient water use on irrigated SMOPS.

- To focus on Integrated Pest Management (IPM) and integrated systems.

Because of the choice made for total decoupling, some of these purposes, and in particular the environmentally oriented ones, can now only be achieved through (the modest funds for) agri-environmental measures or through cross compliance requirements. In fact, with the integration in the SPS, cross compliance has become obligatory. As for other crop or animal production, olive growers will only be able to benefit from support if they comply with certain rules of good agricultural and environmental practices defined by each Member State. These policy changes are likely to have important consequences, in particular for farms with small traditional or semi-intensive (environmentally friendly) olive production systems. These farms have no opportunity to increase subsidy payments by increasing production, and they now have to comply with obligatory cross compliance regulations. Since the target area in Portugal is mainly comprised of such small farms, the focus will be on that area.

In this paper we investigate first which cross compliance regulations are being applied or considered with regard to erosion control in olive groves in different countries, and what cost and benefit repercussions this will have for small olive farmers on sloping land. Thereafter an analysis will be made, for a case study in Trás-os-Montes (ToM) in northeast Portugal, of the effects of cross compliance obligations on the respective production systems with their economic and environmental features.

\section{Materials and methods}

\section{Data set on olive production}

This study has made use of the extensive data set from the OLIVERO project. In all five target areas (Fig. 1) agro-socio-economic surveys were held, with sample size ranging from 60 to 235 farms (Duarte(Ed.), 2005). A SMOPS typology was developed for each area based on these surveys. This was followed by a detailed analysis of production costs for these various SMOPS types in the target areas (Fleskens (Ed.), 2005). These survey and production cost data have been used, in combination with experimental data, to assess the costs and benefits of good agricultural practices and cross compliance for the respective SMOPS and target areas (Martínez Raya et al., (Eds.), 2006).In each country, legal documents were consulted in order to obtain detailed information on the cross compliance

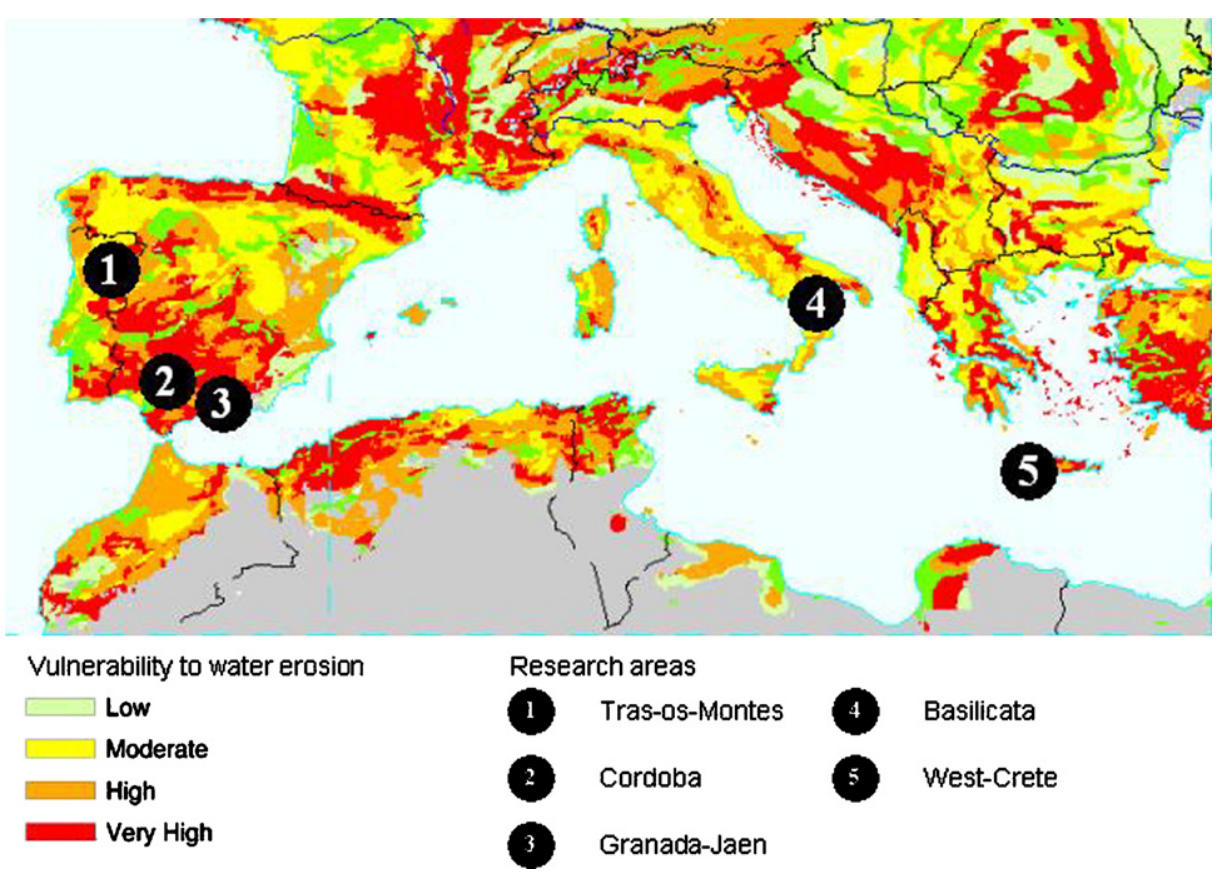

Fig. 1. Vulnerability of the Mediterranean basin to water erosion (after U.S. Department of Agriculture, 1998) and location of the five OLIVERO research sites. 
regulations for erosion control measures in olive groves. For these erosion control measures the costs and effects were calculated on the basis of the above-mentioned studies on costs and benefits of good agricultural practices. The results are shown in section "Cross compliance aimed at soil erosion control in olive orchards".

\section{Scenario development}

Since the project was focussed on the future of olive groves on sloping and mountainous land, some alternative scenarios were subsequently developed for production and natural resource conservation in the target areas. A linear programming simulation model has been developed for this purpose, with the use of GAMS (Brooke et al., 1998), to assess the various socio-economic and environmental effects of changes between different SMOPS types, including abandonment. While aiming at the highest possible annual net returns from olive production over the period 2005-2030, the model includes various constraints, such as constant total area, limited family and hired labour supply, minimum return to labour, annual amount of finance for investment, time lapse for production changes, subsidy levels, budget for agrienvironmental measures, etc. The minimum return to labour constraint is an important factor, since sustainable farms should earn a decent remuneration, even though the opportunity costs of labour is in many cases below the prevalent wage rate. Therefore the simulation is undertaken for both a situation with and without the minimum return to labour constraint.

For convenience reasons use has been made of a hypothetical area of 10 units (ha or 1000s of ha), at the start showing the 2005 distribution of SMOPS as existing in the target area. The model includes various environmental indicators that are affected by the changes of SMOPS, such as soil loss, wildfire risk, water use, biodiversity, pollution, etc.

Influencing variables are the labour cost and olive oil prices as well as the level of subsidies. Both market prices of olive oil and wage rates were considered either to remain at constant levels or to increase at $2 \%$ per year. The EU policy changes are assumed to lead to subsidy reductions after 2013 of either $2 \%$ per year (moderate) or $4 \%$ per year (strong). Of the eight possible different combinations (of the three influencing variables), four options have been selected and given appropriate names: Stable market (constant prices and moderate subsidy reduction); Bright market (increasing oil prices and moderate subsidy reduction); Doom market (increasing wages and strong subsidy reduction) and the Bleak market scenario (increase of both oil prices and wages, and strong subsidy reduction). The model has been run for all five target areas. Details on the model and its results are presented in Fleskens and de Graaff (2006).

In section "Simulation case study on the future of olive groves and the effects of cross compliance" of this paper the results for the Trás-os-Montes area will be highlighted in a case study, in which the effects of cross compliance on the future production and environmental features of olive groves will be analysed.

\section{Cross compliance aimed at soil erosion control in olive orchards}

\section{Cross compliance requirements}

Cross compliance is the practice of granting public payments to farmers only if they comply with certain environmental standards (Mann, 2005). Shiferaw and Holden (2000) use the term interlinkage: conservation objectives are linked to access to certain farm programme benefits (here: subsidies) that are made contingent upon installing erosion control practices on erodible land.
While direct subsidies can distort price signals and negatively affect the environment, the idea is that the combination of subsidies with cross compliance rules for conservation could be beneficial for both socio-economic welfare and the environment.

Under the new SPS policy, farmers may receive payments provided that they maintain their land in good agricultural condition and comply with the standards on public health, animal and plant health, the environment and animal welfare (EU Council Regulation no. 1782, 2003). If a farmer fails to comply with these rules through negligence, direct payments may be reduced by $5-15 \%$; in case of deliberate non-compliance, payments may be reduced by at least $20 \%$ and eventually up to $100 \%$ (Martínez Raya et al., (Eds.), 2006).

Cross compliance in the EU-CAP context and for olive orchards in particular is aimed at: (1) avoiding soil erosion; (2) maintaining soil organic matter content; (3) maintaining soil structure; (4) ensuring proper maintenance of land and landscape, and (5) avoiding degradation of habitats (EC, 2005). Although the second, third and fourth aims also relate indirectly to soil erosion risk, we will focus mainly on those cross compliance regulations that have a direct relation with soil erosion risk in olive groves.

In Andalucia in Spain the following regulations have been established for avoidance of soil erosion (Consejería de Agricultura y Pesca, 2005; Boja no. 1330):

- Tillage cannot be applied on plots with slopes of $15 \%$ or more; tillage can be substituted by clearing.

- When the soil is kept bare under the trees by means of herbicides, a vegetative band has to be kept along the contour lines for plots with average slope above $10 \%$.

- Grubbing out of trees is not permitted on plots with slopes above $15 \%$, except when these are replaced by other trees.

- Terraces must be kept in good state of conservation, with good draining capacity and without gullies. After exceptional rains a period of 1 year is allowed for reparation.

In Greece a total of 17 cross compliance rules for olive groves are mentioned, three of which relate directly to soil erosion (Martínez Raya et al., (Eds.), 2006):

- On land with slopes above $10 \%$ a vegetative cover should be kept during the rainy season.

- On land with slopes above $10 \%$ tillage should be practiced along the contour lines or diagonally. Alternatively, vegetative strips should be established to control runoff. Additionally, irrigation should not be applied through flooding.

- Stone terraces or natural vegetation in hedgerows of parcels should not be destroyed or removed.

In Italy, erosion-related regulations vary per region and the text provides many details, but it can be summarised (for Basilicata region) as follows (Legge Regionale, no. 13, 22-02-2005, art. 9; and Decreto 15-12-2005 no. 4432):

- On sloping, not permanently covered land, drainage canals have to be established to evacuate surplus water properly. In Basilicata province it is specified that these canals should not be further apart than $80 \mathrm{~m}$.

- On land with slope above $8 \%$, as an alternative to drainage canals, grass strips (not further apart than $60 \mathrm{~m}$ ) could be established along the contour lines.

- It is prohibited to eliminate existing terraces and to carry out unauthorised levelling.

In Portugal, the regulations were not yet officially established in 2006, but are likely to resemble those for arable crops and to follow earlier rules (Despacho Normativo no. 7/2005): 
- Parcels should have (natural or seeded) vegetative cover between 15th November and 1st of March of the following year.

- Olive grove grubbing out must be authorised by Ministry of Agriculture Municipality Delegations.

- Existing terraces should be properly maintained.

During a visit to an olive growing area in southern Spain in June 2007, it appeared that farmers were not yet (fully) acquainted with the cross compliance rules, despite large numbers of special brochures available at offices of (non-) governmental agencies. The situation in the target area in Portugal was quite similar and also complicated, since the rules were not validated yet in 2007 .

\section{Consequences of application of cross compliance}

In summary, obligatory cross compliance for farmers on sloping and mountainous land will generally concern:

1. a reduction of tillage, with or without temporary cover crops or strips;

2. a restriction with regard to grubbing out of old and unproductive trees;

3. efforts to maintain existing terraces properly.

The application of specific measures to comply with cross compliance may involve additional costs and/or could have an effect on crop yield and farm income. This will be analysed below for the three major requirements summarised above.

\section{Tillage and cover crops}

An analysis of the effects on reduced tillage costs and benefits (yield changes) was made in the framework of the EU Olivero project (Martínez Raya et al., (Eds.), 2006). This yielded some indicative cost figures for three different target areas in southern Europe (Tables 1 and 2). Table 1 shows the effects of this change of management (from current to improved situation) for four different SMOPS in the Granada and Jaen (GJ) target area, for which soil erosion was a key issue. It shows that the total costs could actually decrease, since the costs of tillage are higher than those for temporary cover crops (killed in spring). But in the semi-intensive low input systems (GJ-1 and GJ-3) the yields and the gross margins are also likely to decrease (e.g. through competition for water; Castro et al., 2006). A reduction of tillage can often result in a decline of yields, as also argued by Lankoski et al. (2006). However, in traditional systems on very steep slopes $(\mathrm{GJ}-4)$ it was found that yields may increase with cover crops (thanks to reduced runoff; Francia Martínez et al., 2006) and that the gross margin may become less negative. However, because of these negative gross margins, many traditional olive groves are not properly managed and these farmers do not easily change their management practices.

Thus, only the semi-intensive high input groves (GJ-2) in this area are likely to benefit from the change. A cover crop reduces costs and this does not affect yields, thanks to the supplementary irrigation now often applied in these systems and made possible on sloping land since the introduction of drip irrigation. The effects of no-tillage on soil erosion can be impressive, but these effects are much less under conditions of heavy rainfall (Table 1 ).

In the target areas in Tras-os-Montes, Portugal (PT), and Crete in Greece (HE), farmers considered soil erosion the major key issue in only a few SMOPS. Instead of (or, sometimes, in addition to minimum) tillage, herbicides or integrated weed management will be used to reduce erosion. Table 2 shows that for the (table) olive groves in Tras-os-Montes (PT3) the change towards improved management increases costs and makes gross margins more negative. However, for the two systems in Crete (HE-1 and HE-3) the change appears to be quite positive, thanks to cost reductions and yield increases, which in the latter case are made possible by irrigation.

The figures in these two tables show that it is not clear in advance whether the net financial benefits from no-tillage will turn out positive or negative.

\section{Grubbing out and replacing old unproductive trees}

Most of the olive groves on sloping and mountainous land, and certainly the traditional ones, are old, often exceeding 50 years. These old trees accumulate more wood, provoking a gradually decreasing leaf/wood ratio with lower harvests. Farmers are not allowed to uproot them, unless they obtain permission and undertake replanting. An alternative is rejuvenation pruning. The cost of the pruning is estimated in Spain at $€ 630 \mathrm{ha}^{-1}$, and after the pruning harvests will be low for about $2-3$ years. Thereafter yields could be $30-50 \%$ higher than before the operation. Furthermore, in some cases the wood could be sold as firewood (Martínez Raya et al., (Eds.), 2006). While this operation seems beneficial, it requires sufficient capital resources, rendering it difficult for small farmers.

\section{Construction and maintenance of terraces}

Construction of terraces can considerably reduce erosion, since terracing decreases slope length, diminishes surface runoff and favours the infiltration of water. However, terrace construction is very expensive. On such slopes, construction costs (using bulldoz-

Table 1

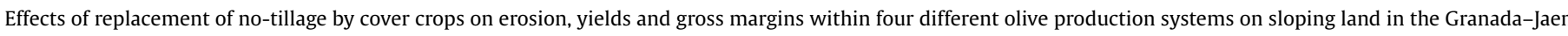
area

\begin{tabular}{|c|c|c|c|c|c|c|}
\hline Situation & Erosion $\left(\mathrm{tha}^{-1} \mathrm{y}^{-1}\right)$ & Yield ( $\left.\mathrm{tha}^{-1}\right)$ & Tillage $\left(€ h a^{-1}\right)$ & Cover crop $\left(€ \mathrm{ha}^{-1}\right)$ & Total cost $\left(€\right.$ ha $\left.^{-1}\right)$ & Gross margin $\left(€ \mathrm{ha}^{-1}\right)$ \\
\hline \multicolumn{7}{|c|}{ GJ-4: traditional system - very steep slope } \\
\hline Current & $>200$ & 1.5 & 76.9 & - & 1078.9 & -179 \\
\hline Improved & $15-210^{\mathrm{a}}$ & 1.6 & - & 59.1 & 1061.1 & -101 \\
\hline \multicolumn{7}{|c|}{ GJ-3: semi-intensive - low input - steep slope } \\
\hline Current & $>100$ & 2.0 & 60.4 & - & 996.5 & 203 \\
\hline Improved & $10-77^{a}$ & 1.9 & - & 45.4 & 981.6 & 158 \\
\hline \multicolumn{7}{|c|}{ GJ-1: semi-intensive - low input } \\
\hline Current & 35 & 2.5 & 41.1 & - & 1036.0 & 464 \\
\hline Improved & 5 & 2.4 & - & 31.7 & 1026.6 & 413 \\
\hline \multicolumn{7}{|c|}{ GJ-2: semi-intensive - high input } \\
\hline Current & 37 & 4.0 & 49.1 & - & 1640.1 & 760 \\
\hline Improved & 6 & 4.0 & - & 31.7 & 1622.7 & 777 \\
\hline
\end{tabular}

Source: Martínez Raya et al., (Eds.), 2006.

Note: Area wise GJ-1 and GJ-2 are the dominant SMOPS.

a Largest figures in case of heavy rainfall. 
Table 2

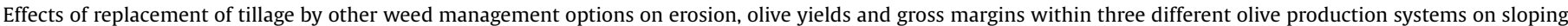
land in Tras-os-Montes and Crete

\begin{tabular}{|c|c|c|c|c|c|c|}
\hline Situation & Erosion $\left(\mathrm{tha}^{-1} \mathrm{y}^{-1}\right)$ & Yield (t ha $\left.{ }^{-1}\right)$ & Tillage $\left(€ \mathrm{ha}^{-1}\right)$ & Weed mgt $\left(€ \mathrm{ha}^{-1}\right)$ & Total cost $\left(€ \mathrm{ha}^{-1}\right)$ & Gross margin $\left(€ \mathrm{ha}^{-1}\right)$ \\
\hline \multicolumn{7}{|c|}{ PT3: semi-intensive-high input, table olive system-Tras-os-Montes } \\
\hline Current & - & 4.0 & 73.2 & - & 1845 & -245 \\
\hline Improved & - & 4.0 & 36.6 & 76.2 & 1882 & -282 \\
\hline \multicolumn{7}{|c|}{ HE-1: traditional system Crete } \\
\hline Current & 5 & 1.85 & 49.1 & 84.5 & 1123 & -198 \\
\hline Improved & 3 & 2.03 & - & 84.5 & 1074 & -56 \\
\hline \multicolumn{7}{|c|}{ HE-3: intensive system Crete, with integrated crop management } \\
\hline Current & 8 & 6.5 & 61.6 & 168.5 & 2684 & 825 \\
\hline Improved & 5 & 6.7 & - & 177.1 & 2631 & 984 \\
\hline
\end{tabular}

Source: Martínez Raya et al., (Eds.), 2006.

ers) are around $€ 2000-4000$ ha $^{-1}$ in Greece and Spain respectively (Martínez Raya et al., (Eds.), 2006). Terraces can also make mechanical cultural practices more difficult, and maintenance is necessary to keep the banks intact and eliminate or reduce weed growth on the risers. Lack of maintenance can eventually cause the collapse of terraces and generate even more erosion. Annual maintenance of terraces is usually estimated at about $5 \%$ of construction costs, or $€ 150 \mathrm{ha}^{-1}$ on average. This corresponds with the amount of $€ 132$ ha $^{-1}$ of agri-environmental aid that can be obtained for this purpose.

These three cross compliance requirements mentioned above constitute important changes in management and often also additional costs that are not always compensated by benefits. The question is: to what extent will farmers feel that they will benefit from these changes, and/or to what extent will they take the risk not to comply if they are of the opinion that these changes are not in their short-term interests? These issues will be discussed in the following case study.

\section{Simulation case study on the future of olive groves and the effects of cross compliance}

\section{The study area in Portugal}

In northeast Portugal, Trás-os-Montes represents around 22\% (72 288 ha) of the national olive grove area and it is the region with the largest number of olive holdings (37344). It has over the years 2002-2004 also been the main Portuguese olive oilproducing region with about 33\% of national production (INE, 2004 and 2005). Olive groves account for $16.5 \%$ of the regional usable arable area (UAA), but in some municipalities this share is above $40 \%$.

However, few farms in Trás-os-Montes are specialist olive growing farms. In fact only around $16 \%$ of the farms and $29 \%$ of the olive grove area belong to this type of farm. Most farms also have other enterprises, such as other permanent crops (e.g. vineyards) or sheep. The average olive orchard's area is only 1.94 ha, although in Mirandela, where olive orchards represent $44 \%$ of the usable arable area, average olive orchard area is 3.4 ha (Duarte et al., in press). This low average grove size confirms the predominance of very small olive producers (those having less than 5 ha of olive grove): they represent $93 \%$ of the farms and $56 \%$ of the olive orchard area. For most of these producers, income comes mainly from off-farm activities, while for the small number of medium and large producers (those with more than 10 ha of olive grove) income comes mainly from agriculture and particularly from olive growing.

Trás-os-Montes is a low-income region where industry is almost absent; the regional economy is highly dependent on agricultural production. Olive production systems strongly contribute to regional income generation and employment, not only directly from olive farms, but also through the associated processing units and services. These contributions help to secure the liveability of a region with a declining population and relatively high levels of illiteracy and unemployment (Duarte et al., 2006).

Table 3 shows some features of five SMOPS identified in the Trás-os-Montes target areas. The PT4 system is in the process of abandonment and not mentioned, while PT9 does not yet exist, but rather is considered as an option for the future. From these SMOPS the traditional system (PT1) associated with a low plant density, old or very old trees and low productivity is the most represented (Figueiredo et al., 2002). This system has important environmental and social functions, such as preventing fire risk, contributing to biodiversity enhancement, and complementing income for many small or very small producers (Duarte et al., in press).

Beyond demographic factors such as the absence of a successor, the total decoupling, as previously discussed, may increase the risk of abandonment that farmers are already facing. So, in this context, specifying the appropriate cross compliance rules could possibly contribute to preventing the negative environmental and social effects of abandonment (e.g. more fire risk, followed by erosion; social isolation of remaining farmers in rural areas).

Table 3

Some features of olive production systems on sloping and mountainous land (SMOPS) in Portuguese target area in Tras-os-Montes

\begin{tabular}{|c|c|c|c|c|c|}
\hline SMOPS: & PT1 (traditional) & PT2 (semi-intensive) & PT3 (semi-intensive (table olives)) & PT5 (organic) & PT9 (new) (intensive) \\
\hline Trees/ha & 100 & 200 & 280 & 100 & 300 \\
\hline Trees' age & $>50$ & 15 & 15 & $>50$ & $<15$ \\
\hline Weed control & Tillage $(2 \times)$ & Tillage $(2 \times)$ & Tillage (2x) & Tillage $(2 \times)$ & Tillage $(2 \times)$ \\
\hline Irrigation & No & No & Drip irrigation & No & Drip irrigation \\
\hline Fertilisation & Once in 2 years & Every year & Every year & Organic & Every year \\
\hline Pest control & None & Two treatments & Two treatments & Organic & Two treatments \\
\hline Pruning & Every 2 years & Every 2 years & Every 2 years & Every 2 years & Every year \\
\hline Harvest & Semi-mechanised & Mechanised & Manual & Mechanised & Mechanised \\
\hline Production (kg/ha) & 1100 & 2250 & 4000 (Table olives) & 900 & 3500 \\
\hline
\end{tabular}


Table 4

Cross compliance conditions, with their estimated environmental effects and additional inputs requirements, per SMOPS type as considered in the model

\begin{tabular}{|c|c|c|c|c|c|c|}
\hline \multirow[t]{2}{*}{ SMOPS } & \multirow{2}{*}{$\begin{array}{l}\text { Initial subsidy amount } \\
\left(€ \mathrm{ha}^{-1} \mathrm{y}^{-1}\right)\end{array}$} & \multicolumn{3}{|c|}{ Cross compliance conditions (their effects on three environmental aspects ${ }^{\mathrm{a}}$ ) } & \multicolumn{2}{|c|}{ Additional inputs required ${ }^{\mathrm{b}}$} \\
\hline & & Winter cover ${ }^{\mathrm{b}}$ & Pruning & Maintenance of terraces & $\begin{array}{l}\text { Labour } \\
\left(\mathrm{h} \mathrm{ha}^{-1} \mathrm{y}^{-1}\right)\end{array}$ & $\begin{array}{l}\text { Variable costs } \\
\left(€ \text { ha }^{-1} \mathrm{y}^{-1}\right)\end{array}$ \\
\hline PTO & - & $-1 / 0 / 1$ & $0 /-0.03 / 0$ & $(-2 / 0 / 2) \times 0.4$ & 20 & 59 \\
\hline PT1 & 223 & $-1 / 0 / 1$ & NA & $(-2 / 0 / 2) \times 0.3$ & 7 & 34 \\
\hline PT2 & 455 & $-1 / 0 / 1$ & NA & $(-2 / 0 / 2) \times 0.1$ & 5 & 18 \\
\hline РТ3 & 645 & $-1 / 0 / 1$ & NA & $(-2 / 0 / 2) \times 0.3$ & 7 & 34 \\
\hline PT5 & 182 & $-1 / 0 / 1$ & NA & $(-2 / 0 / 2) \times 0.2$ & 6 & 26 \\
\hline PT9 & - & $-1 / 0 / 1$ & NA & NA & 4 & 10 \\
\hline
\end{tabular}

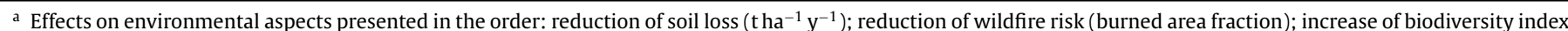
value (dimensionless). For maintenance of terraces also fraction of area initially under terraces is indicated (multiplication).

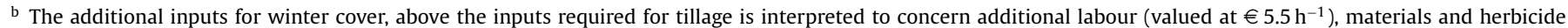
application $\left(71 \mathrm{ha}^{-1} \mathrm{y}^{-1}\right)$.

\section{Cross compliance in the scenarios}

With the linear programming model, the future combination of olive production systems and the resulting state of environmental indicators were analysed first, and thereafter the effects of cross compliance on the future production and environmental features were assessed. This is presented here for the Tras-os-Montes area.

Cross compliance in the model determines whether a farmer receives the full subsidy under the SPS. The amount of the initial SPS payment is based on the production in the reference period (1999-2002), i.e. $€ 223 \mathrm{ha}^{-1}$ for traditional groves (PT1), $€ 455 \mathrm{ha}^{-1}$ for semi-intensive low input groves (PT2), $€ 645 \mathrm{ha}^{-1}$ for semi-intensive high input groves (PT3, geared towards table olive production), and $€ 182 \mathrm{ha}^{-1}$ for organic olive groves (PT5). While olive groves could be abandoned (PT0) or be intensified (PT9), subsidies will in principle remain at the level of the situation in the reference period.

A constraint determines the total annual eligibility for the single farm payment. There is a penalty of $5 \%$ for areas not compliant with cross compliance rules, and additional penalties of $10 \%$ and $5 \%$ respectively for second year and third year non-compliant areas. Any area with a non-compliance history of more than 3 years is considered not eligible for subsidies under the single farm payment scheme.

In order to qualify for cross compliance, certain management interventions are required, as shown in section "Cross compliance aimed at soil erosion control in olive orchards". These are indicated in Table 4 (under cross compliance conditions), with their effects on erosion, wildfire risk and biodiversity, and their additional input requirements. The figures $-1 / 0 / 1$ refer respectively to reduction of erosion with $1 \mathrm{tha}^{-1} \mathrm{y}^{-1}$, zero effects on wildfire risk and one unit increase in biodiversity. Winter cover management (less tillage, but herbicide use) is required in all SMOPS; this is assumed here to require 4 man-hours and $€ 10$ more than conventional tillage.
Terraces occur in different systems, in particular in traditional and semi-intensive high input SMOPS, and because of the steep slopes terraced fields have a relatively high risk of being abandoned. Terrace maintenance reduces erosion with 2 t ha ${ }^{-1} y^{-1}$, increases the biodiversity index with 2 units and requires 10 man-hours and $€ 80$ material costs. For the respective SMOPS the area actually terraced ranges from about $10 \%$ to $40 \%$ and a fraction is shown for maintenance requirements. In the model it has been assumed, as shown in Table 4, that winter cover and terrace maintenance will for all SMOPS reduce soil loss by 1 and $2 \mathrm{tha}^{-1} \mathrm{y}^{-1}$ respectively in this area with average erosion rates of about $3-4 \mathrm{tha}^{-1} \mathrm{y}^{-1}$. Farmers with abandoned groves can still obtain subsidies, as long as they apply pruning (for fire control) and maintain terraces. This pruning requires 12 man-hours and $€ 7$ for material costs.

\section{Results of the scenario studies}

\section{Effects of scenarios on SMOPS distribution}

Based on the different structural features and production costs of the SMOPS the model reallocates the olive grove area, both through abandonment and by changes towards other (existing and one new) SMOPS. These changes, taking place gradually (in steps) in the period 2005-2030, are shown in Tables 5 and 6 for the four scenarios in the Trás-os-Montes region in Portugal. Apart from the percentage distribution of SMOPS over the total area, the tables also show, in the column on the right, which percentage of farmers will comply with the regulations under the respective scenarios. In Table 5 it is assumed that a minimum return to labour (equal to local wage rate) is required, and results are shown for a situation without and with the (costs of) cross compliance obligations. In Table 6 the minimum return to labour constraint is removed, which would imply that farmers do not mind receiving a low remuneration for their labour.

Table 5

Distribution of total area under olives in Tras-os-Montes over different SMOPS considering a minimum return to labour constraint (percentages)

\begin{tabular}{|c|c|c|c|c|c|c|c|}
\hline Scenario and year: & Traditional (PT1) & Semi-low input (PT2) & Semi-high input (PT3) & Intensive (PT9) & Organic (PT5) & Abandoned (PT0) & Cross-compliance (\%) \\
\hline In 2005 & 59 & 29 & 6 & 0 & 6 & 0 & Not obligatory \\
\hline \multicolumn{8}{|c|}{ A: with cross compliance obligations } \\
\hline Stable 2030 & 12 & 0 & 6 & 1 & 0 & 81 & 81 \\
\hline Bright 2030 & 1 & 90 & 0 & 9 & 0 & 0 & 84 \\
\hline Doom 2030 & 0 & 0 & 0 & 0 & 0 & 100 & 23 \\
\hline Bleak 2030 & 1 & 1 & 0 & 15 & 0 & 83 & 19 \\
\hline \multicolumn{8}{|c|}{ B: without cross compliance obligations } \\
\hline Stable 2030 & 11 & 0 & 6 & 9 & 40 & 33 & - \\
\hline Bright 2030 & 0 & 20 & 0 & 80 & 0 & 0 & - \\
\hline Doom 2030 & 1 & 1 & 6 & 5 & 0 & 87 & - \\
\hline Bleak 2030 & 0 & 66 & 0 & 6 & 0 & 28 & - \\
\hline
\end{tabular}


Table 6

Distribution of total area under olives in Tras-os-Montes over different SMOPS, without a minimum return to labour constraint (percentages)

\begin{tabular}{|c|c|c|c|c|c|c|c|}
\hline Scenario and year & Traditional (PT1) & Semi-low input (PT2) & Semi-high input (PT3) & Intensive (PT9) & Organic (PT5) & Abandoned (PT0) & Cross-compliance (\%) \\
\hline In 2005 & 59 & 29 & 6 & 0 & 6 & 0 & Not obligatory \\
\hline \multicolumn{8}{|c|}{ A: with cross compliance requirements } \\
\hline Stable 2030 & 22 & 0 & 6 & 2 & 40 & 30 & 89 \\
\hline Bright 2030 & 0 & 18 & 0 & 82 & 0 & 0 & 89 \\
\hline Doom 2030 & 15 & 0 & 6 & 4 & 47 & 28 & 85 \\
\hline Bleak 2030 & 0 & 78 & 0 & 0 & 0 & 22 & 86 \\
\hline \multicolumn{8}{|c|}{ B: without cross compliance requirements } \\
\hline Stable 2030 & 1 & 0 & 6 & 9 & 60 & 23 & - \\
\hline Bright 2030 & 0 & 19 & 0 & 81 & 0 & 0 & - \\
\hline Doom 2030 & 1 & 0 & 6 & 9 & 60 & 23 & - \\
\hline Bleak 2030 & 0 & 66 & 0 & 6 & 0 & 28 & - \\
\hline
\end{tabular}

In all but the Bright market scenario in Table 5, considerable abandonment is projected, in particular in the situation with cross compliance obligations. And the cross compliance obligations seem somehow to restrain the move towards more productive systems, e.g. in the Bright market scenario from semi-low input to intensive systems. In Table 6 , without the minimum return to labour constraint, this is less pronounced, but also visible in the move from traditional to organic systems in the Stable and Doom market scenarios.

Both tables show that the model predicts a move away from traditional systems: towards semi-intensive low input systems (in Bright and Bleak scenarios), towards intensive systems (in Bright scenario) and towards organic systems (in Stable and Doom scenarios). The semi-intensive high input system constitutes a special case (table olives), whereby groves are either retained (in Stable and Doom scenarios) or abandoned.

The figures in the column on the right indicate that farmers would fulfil the cross compliance obligations to some extent even after abandonment, in order to remain eligible for subsidies, in particular in the Stable market scenario. On the other hand, cross compliance obligations (costs) seem to lead to more abandonment.

Table 6 represents for all but the Bright market scenarios a continuation of less intensive olive production, whereby the return to labour remains below the local wage rate and which constitutes to some extent "hobby farming". It is important to note that the present situation (2005) is also not economically feasible at market wage rates, so that the results in Table 5 clearly overestimate abandonment rates. In any case, abandonment rates of nearly $100 \%$ are unrealistic, but this is just a model output. Still, in Table 6 abandonment of about $20-30 \%$ of olive groves occurs in all but the Bright market scenario. Labour-extensive organic olive production may then become an important production system under these 'hobbyfarming conditions'.

In general, a rising olive oil price triggers the intensification process (Bright scenario), while stable oil prices lead to exten- sive systems (Stable scenario) or abandonment (Doom scenario), depending on the trend of the price of labour (wages).

\section{Effects of scenarios on income, soil erosion and other environmental factors}

Tables 7 and 8 show the effects of the four scenarios on income, on employment and on soil erosion and other environmental factors. These effects strongly relate to the trends in SMOPS area distribution, and a high level of abandonment automatically leads to low levels of income and employment and lower levels of erosion, water use and pollution.

This is most apparent in Table 7, which concerns the situation with the minimum return to labour constraint, as in Table 5. Large scale abandonment under cross compliance conditions would on the one hand bring positive environmental effects (less water use and pollution), but would on the other hand increase the fire risk because of a lack of pruning and undergrowth between the rows. In the Stable market scenario, in which farmers still respect cross compliance despite massive abandonment, it will also reduce soil erosion.

With no cross compliance obligations, the minimum return to labour constraint appears to be binding only in the Doom market scenario (as witnessed by high abandonment in Table 5). Therefore the figures under $B$ in the two Tables 7 and 8 are quite similar for the three other scenarios.

In most scenarios cross compliance measures help to reduce both erosion and pollution, but they have a certain depressing effect on income due to higher abandonment and less intensification.

It should be realised that the relatively high income levels in the Bright market scenario are not only due to higher production (intensive system), but also to the higher prices and subsidies and lower labour costs in that scenario.

The calculations have been made for the average situation, whereby only part of the unit area is terraced and incurs maintenance costs. A farmer who has all of his olive land under terraces will

Table 7

Effects of scenarios on environmental factors in the Trás-os-Montes, with minimum return to labour constrain

\begin{tabular}{|c|c|c|c|c|c|c|}
\hline Scenario and year & Income $\left(€ \mathrm{ha}^{-1} \mathrm{y}^{-1}\right)$ & Labour $\left(\mathrm{hy}^{-1}\right)$ & Erosion $\left(\mathrm{tha}^{-1} \mathrm{y}^{-1}\right)$ & Fire risk (burnt $(\%) \mathrm{y}^{-1}$ ) & Water use $\left(\mathrm{m}^{3} \mathrm{ha}^{-1} \mathrm{y}^{-1}\right)$ & Pollution index ${ }^{\mathrm{a}}$ \\
\hline In 2005 & 307 & 1329 & 3.1 & 0.09 & 90 & 2.6 \\
\hline \multicolumn{7}{|c|}{ A: with cross compliance obligations } \\
\hline Stable 2030 & 248 & 494 & 0.9 & 0.16 & 104 & 0.5 \\
\hline Bright 2030 & 820 & 1310 & 3.8 & 0.07 & 184 & 5.1 \\
\hline Doom 2030 & 52 & 53 & 1.6 & 0.19 & 3 & 0.0 \\
\hline Bleak 2030 & 272 & 341 & 2.0 & 0.17 & 293 & 0.8 \\
\hline \multicolumn{7}{|c|}{ B: without cross compliance obligations } \\
\hline Stable 2030 & 393 & 867 & 1.9 & 0.11 & 275 & 4.6 \\
\hline Bright 2030 & 1047 & 1870 & 3.4 & 0.03 & 1598 & 5.1 \\
\hline Doom 2030 & 256 & 323 & 2.2 & 0.18 & 192 & 0.7 \\
\hline Bleak 2030 & 732 & 908 & 4.1 & 0.11 & 120 & 3.7 \\
\hline
\end{tabular}

a Pollution index value, based on pesticide and nitrogen application. 
Table 8

Effects of scenarios on environmental factors in the Trás-os-Montes, without minimum return to labour constraint

\begin{tabular}{|c|c|c|c|c|c|c|}
\hline Scenario and year & Income $\left(€ \mathrm{ha}^{-1} \mathrm{y}^{-1}\right)$ & Labour $\left(\mathrm{hy}^{-1}\right)$ & Erosion $\left(\mathrm{tha}^{-1} \mathrm{y}^{-1}\right)$ & Fire risk (burnt $(\%) \mathrm{y}^{-1}$ ) & Water use $\left(\mathrm{m}^{3} \mathrm{ha}^{-1} \mathrm{y}^{-1}\right)$ & Pollution index ${ }^{\mathrm{a}}$ \\
\hline In 2005 & 307 & 1329 & 3.1 & 0.09 & 90 & 2.6 \\
\hline \multicolumn{7}{|c|}{ A: with cross compliance obligations } \\
\hline Stable 2030 & 324 & 922 & 0.6 & 0.11 & 121 & 4.2 \\
\hline Bright 2030 & 1015 & 1922 & 2.5 & 0.03 & 1632 & 5.1 \\
\hline Doom 2030 & 260 & 932 & 0.6 & 0.11 & 165 & 5.0 \\
\hline Bleak 2030 & 690 & 985 & 3.3 & 0.10 & 0 & 4.0 \\
\hline \multicolumn{7}{|c|}{ B: without cross compliance obligations } \\
\hline Stable 2030 & 378 & 920 & 1.6 & 0.10 & 275 & 6.5 \\
\hline Bright 2030 & 1050 & 1884 & 3.4 & 0.03 & 1629 & 5.1 \\
\hline Doom 2030 & 310 & 920 & 1.6 & 0.10 & 275 & 6.5 \\
\hline Bleak 2030 & 732 & 908 & 4.1 & 0.11 & 120 & 3.7 \\
\hline
\end{tabular}

a Pollution index value, based on pesticide and nitrogen application.

incur much higher costs for cross compliance: a total of $€ 167 \mathrm{ha}^{-1}$ (at market wage rate), which is quite close to the amount of subsidy he could get for traditional SMOPS $\left(€ 223 \mathrm{ha}^{-1}\right)$. If he abandons the grove and would still like to receive the subsidy, he would also have to undertake pruning at $€ 73$, and then the costs will exceed the subsidy. These calculations do not even include the costs of other cross compliance obligations, e.g. with regard to avoiding degradation of habitats. Semi-intensive high input SMOPS with their higher subsidy levels could, on the other hand, much more easily bear these costs of cross compliance measures.

\section{Discussion and conclusions}

Mann (2005) looked at different perspectives of cross compliance, focussing on the situation in Switzerland, where it has been widely applied and led to major changes in farming. He concluded that transaction cost advantages justify cross compliance only in few cases, and that it usually would be more efficient to decouple social and environmental policies. However, this depends on the perspective and on the objectives of cross compliance, or whether it could contribute simultaneously to efficiency, equity and environmental stewardship.

The past olive oil subsidy regime, with payments based on amounts of oil produced, has led to intensification of production and adverse environmental effects, in particular soil erosion. Under that regime obligatory cross compliance could probably have been an important policy instrument for environmental and equity reasons. Under the new subsidy regime with fixed payments based on previous performance, the incentives to intensify olive groves at high environmental costs have decreased and cross compliance is less urgent in that respect.

Cross compliance is principally aimed at higher environmental sustainability, and the scenario studies show that they are likely to be effective in controlling soil erosion and pollution. However, the scenario analysis also shows that SMOPS that presently seem to be environmentally friendly (traditional, organic and abandoned ones) have to incur the highest costs (Table 4), but are the ones least likely to respect the cross compliance obligations. The analysis also shows that these obligations may actually lead to higher abandonment, and that they somehow restrain the move towards more intensive grove systems. The former conclusion is in contradiction with the opinion of policy-makers (at least in Portugal), that cross compliance will be an effective instrument to prevent abandonment, considering that farmers will lose the benefit of the subsidies after three years of non-compliance.

Traditional farms on steep land already have negative financial returns and can only continue their olive production when they accept lower opportunity costs of their labour. In 1999-2002 they had low production levels, and under the new subsidy regime
(Single Payment Scheme) can longer obtain more subsidy through better management. They will therefore be less eager to undertake cross compliance measures, and may take the chance that their subsidy will be reduced in the first year by some $5 \%$. In the case that they will be caught for non-compliance, they could still start applying the measures in the next year. The risk of being caught for non-compliance is rather low anyhow, at least in remote areas.

It is therefore unfortunate that the producing countries have decided to choose more or less complete decoupling, eliminating the options for national envelopes to cater to environmental and social improvements in the olive sector. The latter idea was probably not worked out yet in sufficiently clear details to convince farmers and policy-makers of their eventual advantages. Besides in Portugal, with predominantly traditional groves, the financial transfer from high- to low-productive groves could not be very significant (since the number of high-productive groves is low).

According to our study, cross compliance as a policy instrument appears to inadvertently lead to a socially unfair distribution of subsidies. This is probably so because the cross compliance conditions do not affect olive producers according to the true environmental impact of their production. The arbitrary choice of erosion control as a main compliance criterion, and the prescription of specific measures as obligatory practices to target erosion, discriminate on the basis of slope. Furthermore, as we have seen, olive groves on sloping land tend to be smallholdings, low productive and environmentally friendly. While the 'polluter pays' principle receives general sympathy and - when pollution is measurable and traceable - can lead to a fair compensation payment and cross compliance is a construct with similar traits, cross compliance is far less transparent to put into practice.

It will be important now to increase the amount of support under the Agri-Environmental Measures (AEM), in particular for the traditional and semi-intensive low input systems, in order to keep them environmentally friendly. On the other hand more attention should be paid to other cross compliance requirements with regard to such environmental aspects as pollution, water use and biodiversity aspects, which are likely to have more effect on the intensive olive production systems. These systems can more easily withstand the costs of the cross compliance requirements.

\section{References}

Beaufoy, G., 2000. The olive oil regime. In: Brouwer, F., Lowe, P. (Eds.), CAP Regimes and the European Countryside. CABI Publishing, Wallingford, UK, pp. 155-177.

Beaufoy, G., 2001. EU Policies for Olive Farming Unsustainable on all Counts WWF/Bird Life International.

Brooke, A., Kendrick, D., Meeraus, A., Raman, R., Rosenthal, R.E., 1998. GAMS: A User's Guide. GAMS Development Corporation, Washington, USA.

Brouwer, F., Lowe, P., 2000. CAP Regimes and the European Countryside. CABI Publishing, Wallingford, UK.

Castro, G., Romero, P., Gómez, J.A., Fereres, E., 2006. Rainfall redistribution beneath an olive orchard. Agricultural Water Management 86, 249-258. 
Consejería de Agricultura y Pesca, 2005. BOJA no. 133. Orden de 23 de Junio de 2005. de Graaff, J. (Ed.), 2005. Perspectives of different types of Sloping and Mountainous Olive Plantation Systems (SMOPS). Olivero Working Paper No. 4.

de Graaff, J., Eppink, L.A.A.J. 1999. Olive oil production and soil conservation in southern Spain, in relation to EU subsidy policies. Land Use Policy, vol. 16, issue 4, pp. 259-267.

de Graaff, J., Duran Zuazo, V., Jones, N., Fleskens, L. Olive production systems on sloping land: prospects and scenarios. Journal of Environmental Management, doi:10.1016/j.jenvman.2007.04.024, in press.

Duarte, F. (Ed.), 2005. Overview of financial farm management data in project areas by farm type and zone. Olivero Working Paper No. 2 .

Duarte, F., Jones, N., Lúcio, C., Nunes, A., 2006, The reform of the olive oil regime and its impacts on the olive and olive oil sector: a case study on Northern Portugal - Trás-os-Montes, New Medit, No. 2.

Duarte, F., Jones, N., Fleskens, L. Traditional olive orchards on sloping land: sustainability or abandonment. Journal of Environmental Management, doi:10.1016/j.jenvman.2007.05.024, in press.

EC, 1997. Note to the council of ministers and to the European parliament on the olive and olive oil sector (including economic, cultural and social and environmental aspects), the current common market organization, the need for a reform and the alternatives envisaged (Options paper). Brussels.

EC, 2003. Communication from the Commission to the Council and the European Parliament: accomplishing a sustainable agricultural model for Europe through the reformed CAP - the tobacco, olive oil, cotton and sugar sectors. Brussels, COM (2003) 554 final, 23 pp.

EC, 2005. Commission Regulation (EC) No. 2183/2005 of 22 December 2005 amending Council Regulation (EC) No. 1782/2003 establishing common rules for direct support schemes under the common agricultural policy and establishing certain support schemes for farmers and amending Regulation (EC) No. 795/2004 laying down detailed rules for the implementation of the single payment scheme provided for in Council Regulation (EC) No. 1782/2003.

Figueiredo, T. de, Almeida, A., Araújo, J., 2002. Edaphic characteristics of olive-tree areas in the Trás-os-Montes Region (Portugal): a map-based approach. Acta Horticultarae (ISHS) 586, 151-154.
Fleskens, L. (Ed.), 2005. Overview of production costs for Sloping and Mountainous Olive Plantation Systems (SMOPS) under different circumstances. Olivero Working Paper No. 3.

Fleskens, L., de Graaff, J., 2006. Future scenarios for olive production systems on sloping land: stakeholder and expert opinions and results from a simulation model. Olivero Project Communication No. 13. Available from: www.olivero.info.

Francia Martínez, J.R., Durán Zuazo, V.H., Martínez Raya, A., 2006. Environmental impact from mountainous olive orchards under different soilmanagement systems (SE Spain). Science of the Total Environment 358, 46-60.

Gómez, J.A., Giráldez, J.V., Fereres, E., 2005. Water erosion in olive orchards in Andalusia (Southern Spain): a review. Geophysical research Abstracts 7, 08406.

Instituto Nacional de Estatística (INE), 2004 and 2005, "Estatísticas Agrícolas", Lisboa.

Lankoski, J., Ollikainen, M., Uusitalo, P., 2006. No-till technology: benefits to farmers and the environment? Theoretical analysis and application to Finnish agriculture. European Review of Agricultural Economics 33, 193-221.

Mann, S., 2005. Different perspectives on cross compliance. Environmental values $14,471-482$.

Martínez Raya, A., García Bolaños, M., Cárceles Rodríguez, B., Francia Martínez, J.R., Martínez Vilela, A., Durán Zuazo, V. (Eds), 2006. Good agricultural practices and cross compliance for olive production systems on sloping land. Olivero Project Communication No. 12.

Metzidakis, I. (Ed.), 2004. An overview of productive, ecological and socio-economic functions of SMOPS. Olivero Project Communication No. 2. Available from: www.olivero.info.

Pastor, M., Castro, J., 1995. Soil management systems and erosion. Olivae 59, 64-74.

Shiferaw, B., Holden, S.T., 2000. Policy instruments for sustainable land management: the case of highland smallholders in Ethiopia. Agricultural economics 22, 217-232.

Stroosnijder, L., Palese, A.M., Mansinho, M.I. OLIVERO, the project analysing the future of olive production systems on sloping land in the Mediterranean basin Journal of Environmental Management, doi:10.1016/j.jenvman.2007.05.025, in press. 